\title{
Research Paper: Health Risk Assessment of Heavy Metals Via the Consumption of Spaghetti
}

\author{
Soheil Sobhanardakani ${ }^{* *}$ iD
}

1. Department of Environment, College of Basic Sciences, Hamedan Branch, Islamic Azad University, Hamedan, Iran.

Citation Sobhanardakani S.Health Risk Assessment of Heavy Metals Via the Consumption of Spaghetti. Journal of Research \& Health. 2020; 10(4):217-224. http://dx.doi.org/10.32598/JRH.10.4.1345.1

http://dx.doi.org/10.32598/JRH.10.4.1345.1

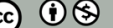

Article info:

Received: 17 Nov 2016

Accepted: 02 Sep 2017

Publish: 01 Jul 2020

\section{Keywords:}

Food safety, Noncarcinogenic, Health impact assessment, Maximum allowable concentration

\begin{abstract}
A B STRACT
Background: It has long been recognized that the intake of foods contaminated with chemicals, especially heavy metals can give rise to acute intoxications. The toxic properties of heavy metals are due to their long biological half-lives, as well as non-biodegradable and persistent composition. Considering the importance of the cereal products in the human diet, the present investigation was carried out to assess the human health risk of residue levels of $\mathrm{Al}, \mathrm{Cr}, \mathrm{Pb}$, and $\mathrm{Zn}$ in the domestic and imported spaghetti.
\end{abstract}

Methods: In this descriptive study, 18 samples of Iranian and imported spaghetti were collected from the market in Kermanshah City, Iran, in 2015. After the preparation and processing of the samples in the laboratory, the concentration of metals was determined using the inductively coupled plasma optical emission spectroscopy. Then, statistical analyses were performed in SPSS (version 19) by running the Shapiro-Wilk test, one-way ANOVA (Duncan multiple range test), Independent t-test , and Pearson correlation coefficient.

Results: The results showed that the mean concentrations of $\mathrm{Al}, \mathrm{Cr}, \mathrm{Pb}$, and $\mathrm{Zn}$ in Iranian spaghetti samples were $655.56 \pm 400.35,211.11 \pm 92.80,2666.67 \pm 948.68$, and $588.89 \pm 116.67 \mu \mathrm{g}$ / $\mathrm{kg}$, respectively and in the imported spaghetti samples, these values were $2022.22 \pm 1940.86$, $677.78 \pm 393.0,3300.0 \pm 728.0$, and $866.67 \pm 685.57 \mu \mathrm{g} / \mathrm{kg}$, respectively. Moreover, Health Risk Index (HRI) values in adults and children via consumption of Iranian and imported spaghetti were within the safe limits (HRI $<1)$.

Conclusion: Considering the serious contamination of some samples of Iranian and imported spaghetti by $\mathrm{Al}$ and $\mathrm{Pb}$, the control of heavy metals content during the whole production processing of spaghetti is suggested.

\section{Introduction}

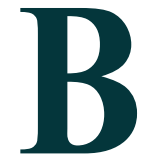

ecause of some properties of heavy metals such as long biological half-lives, non-biodegradable potential, and bioaccumulation potential, they can threaten human health through the soil-plant-food chain contamination. Heavy metals are potential environmental contaminants with the ability to cause adverse health effects such as causing diseases, disorders, malfunctions, and malformations in humans if they appear in excess amounts in the foods consumed by the human being [1-4].

* Corresponding Author:

Soheil Sobhanardakani, PhD.

Address: Department of Environment, College of Basic Sciences, Hamedan Branch, Islamic Azad University, Hamedan, Iran

Phone: +98 (918) 3172286

E-mail: s_sobhan@iauh.ac.ir 
Some of the trace elements such as Zinc ( $\mathrm{Zn})$, iron $(\mathrm{Fe})$, and Copper $(\mathrm{Cu})$ are found in living organisms and considered essential components (i.e. indispensable for health and growth); whereas, other metals are not [5-7]. However, it should be noted that some of these non-essential trace elements can be beneficial to human health via their pharmacological properties $[6,8,9]$.

Aluminum ( $\mathrm{Al}$ ) is not an essential element for humans; nevertheless, it is prevalent in water, air, plants, and consequently in all foods $[3,10]$. Chromium (VI) or Cr (VI) is toxic and known human carcinogens; whereas, $\mathrm{Cr}$ (III) is an essential element. Chromium is mainly used in stainless steel production. Therefore, stainless steel vessels seem to be the main source of $\mathrm{Cr}$ contamination $[11,12]$. Lead $(\mathrm{Pb})$ is present in the environment because of air, water, and soil pollution. Major sources of this element include fuel combustion, industrial gases, liquid effluents, and agricultural inputs such as some pesticides and phosphate fertilizers $[11,13]$. Lead poisoning in adults can affect renal blood flow as well as peripheral and central nervous systems [14]. Furthermore, fetuses, infants, and children are at particularly high risk from neurotoxic and development disorders of this element $[15,16]$. However, $\mathrm{Zn}$ is known as an essential structural and functional element for numerous cellular processes [17].

Risk assessment includes scientific analyses whose results can be presented quantitatively or qualitatively the likelihood of harm associated with exposure to chemical compounds. In this regard, the human health risk assessment requires identification, collection, and integration of information on health hazards of the chemicals, exposure of humans to the chemicals, and relationships between exposure, dose, and adverse effects $[18,19]$.

The Acceptable Daily Intake (ADI) of heavy metals was compared with the oral Reference Dose (RfD) or Provisional Tolerable Weekly Intake (PTWI) to examine the potential health risks. Following the standard methods (US EPA), the Health Risk Index (HRI) or Target Hazard Quotients (THQ) are explained as the ratio of the dose resulting from exposure to site media to the dose that is believed to be safe, even in sensitive individuals such as children and elderly. If the $\mathrm{HRI}<1$, no significant risk of chronic-toxic effects exists. If the HRI $>1$, chronic-toxic effects may occur [20,21].

The literature review mentions that the estimated dietary intakes of $\mathrm{Cr}, \mathrm{Pb}$, and $\mathrm{Zn}$ via the consumption of potato/corn chips were $0.37,0.23$, and $33.75 \mu \mathrm{g} / \mathrm{kg} / \mathrm{d}$ for children, respectively and were $0.06,0.04$, and 5.19 $\mu \mathrm{g} / \mathrm{kg} / \mathrm{d}$ for adults, respectively [22]. Filon et al. (2013) reported that the mean content of $\mathrm{Pb}$ in wheat flour consumed in Poland was $0.076 \pm 0.0448 \mathrm{mg} / \mathrm{kg}$ [23]. Iwegbue (2012) reported that the contents of $\mathrm{Cr}, \mathrm{Pb}$, and $\mathrm{Zn}$ in some brands of biscuits marketed in Nigeria were in the range of $0.39-0.72,<0.001-1.07$, and $29.06-49.27 \mu \mathrm{g} / \mathrm{g}$, respectively [24].

Owing to the possibility of heavy metals accumulation in agricultural products such as cereals and cereal products through irrigation with contaminated water or wastewater, overuse of metal-containing pesticides or chemical and organic fertilizers, atmospheric deposition of heavy metals, production process and packaging [2, $3,25]$, the present study was conducted to analyze and assess the non-carcinogenic health risk of the $\mathrm{Al}, \mathrm{Cr}, \mathrm{Pb}$, and $\mathrm{Zn}$ through consumption of some Iranian and imported spaghetti marketed in the city of Kermanshah in 2015

\section{Methods}

In this study, the standard stock solutions of different metal ions at the concentration of $1000 \mu \mathrm{g} / \mathrm{mL}$ were used to prepare working solutions after appropriate dilution. Standard solutions were of analytical grade (Merck, Darmstadt, Germany). Distilled deionized water was used in all dilution procedures.

The sample collection was performed according to the Cochran formula of $\mathrm{SS}=\mathrm{Z} 2 \times(\mathrm{p}) \times(1-\mathrm{p}) / \mathrm{c} 2$ and also considering the constraints of time and budget. For this purpose, 9 samples of Iranian raw spaghetti and 9 samples of imported raw spaghetti were chosen randomly from the market basket of people inhabited in the city of Kermanshah, Iran, in autumn 2015. In the laboratory, $5 \mathrm{~g}$ of each sample was placed in crucibles and few drops of concentrated HNO3 were added as an ashing aid. The dry-ashing process was carried out in a muffle furnace by a stepwise increase of the temperature up to $550^{\circ} \mathrm{C}$ and then left to ash at this temperature for $4 \mathrm{~h}$. Next, the ash was left to cool down and rinsed with $1 \mathrm{M} \mathrm{HNO3.}$ The ash suspension was filtered by Whatman filter paper grade 42 (Sigma-Aldrich, Germany) and the filtrate made up to the volume of $25 \mathrm{~mL}$ with $1 \mathrm{M} \mathrm{HNO3} \mathrm{[2]}$ The analysis of $\mathrm{Al}, \mathrm{Cr}, \mathrm{Pb}$, and $\mathrm{Zn}$ was performed by inductively coupled plasma mass spectrometry (Varian, 710-ES, Australia) with three replications (wavelength for $\mathrm{Al}, \mathrm{Cr}, \mathrm{Pb}$, and $\mathrm{Zn}$ were $308.2,267.7,220.3$, and $206.2 \mathrm{~nm}$, respectively). To check the accuracy of the analytical method, a multi-element standard solution (Merck, Germany) with different concentrations of $\mathrm{Al}$, $\mathrm{Cr}, \mathrm{Pb}$, and $\mathrm{Zn}(100,500,1000,2500,5000 \mathrm{ppb})$ were used for the calibration. 
In the current study, the potential health risks due to exposure to elements were assessed. For doing so, the average Daily Intake of Metal (DIM) was computed with Equation 1 [4, 26-28]:

$$
\text { 1. DIM }=\frac{\text { Cmetal } \times \text { Cfactor } \times \text { Dfood intake }}{\text { Baverage weight }}
$$

where Cmetal, Cfactor, Dfood intake, and Baverage weight are respectively the heavy metal concentrations in spaghetti ( $\mathrm{mg} / \mathrm{kg})$, conversion factor, daily intake of spaghetti $(\mathrm{kg} / \mathrm{d})$, and average body weight $(\mathrm{kg})$. The conversion factor $(0.085)$ is used to convert fresh weight into dry weight [29]. The average daily intake of spaghetti for adults and children is considered $0.02 \mathrm{~kg}$ per person per day [29]. The average adult and children's body weight are considered as 70.0 and $15.0 \mathrm{~kg}$, respectively [30-32].

The HRI for the local population through the consumption of spaghetti was assessed using Equation 2 [26-28]:

$$
\text { 2. } H R I=\frac{\mathrm{DIM}}{\mathrm{RfD}}
$$

Here, DIM and RfD represent daily intake of metal and reference dose of metal, respectively. The oral reference doses for $\mathrm{Al}, \mathrm{Cr}, \mathrm{Pb}$, and $\mathrm{Zn}$ were 0.02, 0.003, 0.0035, and $0.30 \mathrm{mg} / \mathrm{kg} / \mathrm{d}$, respectively. An HRI of $<1$ means the exposed population is assumed to be safe $[21,33,34]$.

The total HRI (THRI) of heavy metals for the spaghetti was calculated as the mathematical sum of each metal HRI value according to Equation 3 [32]:

\section{3.}

$$
\begin{aligned}
& \text { THRI }=\text { HRI }(\text { toxicant } 1)+\text { HRI }(\text { toxicant } 3) \\
& +\ldots+\text { HRI }(\text { toxicant } n)
\end{aligned}
$$

The statistical analysis of the obtained results was performed first by the Shapiro-Wilk test for checking data normality, followed by the One-way Analysis of Variance (ANOVA) for statistical grouping of the mean concentrations of $\mathrm{Al}, \mathrm{Cr}, \mathrm{Pb}$, and $\mathrm{Zn}$ between samples. Moreover, the concentrations of the analyzed elements between Iranian and imported samples were compared by the independent t-test. Finally, to study a correlation between the metals in the different samples, the Pearson correlation coefficient was performed. A probability level of $\mathrm{P}=0.05$ was considered statistically significant.

\section{Results}

Table 1 presents the concentrations of $\mathrm{Al}, \mathrm{Cr}, \mathrm{Pb}$, and $\mathrm{Zn}$ in the analyzed spaghetti samples. Data in Table 1 show that among the analyzed Iranian spaghetti samples, $\mathrm{Al}, \mathrm{Cr}, \mathrm{Pb}$, and $\mathrm{Zn}$ were detected in amounts ranging from 300 to 1500,100 to 400,2000 to 5000, and 400 to $800 \mu \mathrm{g} / \mathrm{kg}$, respectively. Furthermore, among the analyzed imported spaghetti samples, $\mathrm{Al}, \mathrm{Cr}, \mathrm{Pb}$, and $\mathrm{Zn}$ were detected in amounts ranging from 300 to 5000,300 to 1400,2200 to 4300 , and 200 to $2500 \mu \mathrm{g} /$ $\mathrm{kg}$, respectively.

However, HRI values in adults and children via consumption of Iranian and imported spaghetti were within the safe limits $(\mathrm{HRI}<1)$ (Table 2). The THRI values for adults via consumption of Iranian spaghetti varied from $1.51 \times 10-2$ to $3.98 \times 10-2$ and for children from $7.04 \times 10-2$ to $1.86 \times 10-1$ and so below the safe limit $($ THRI $<1)$. Similarly, the THRI values for adults via consumption of imported spaghetti varied from $1.81 \times 10-2$ to $4.74 \times 10-2$ and for children from $8.43 \times 10-2$ to $2.21 \times 10-1$, so they were below the safe limit $(\mathrm{THRI}<1)$. Therefore, the consumption of Iranian and imported spaghetti has no potential health risk for adults and children.

Based on the results of the Pearson correlation coefficient, no significant correlations were found between the concentration of the metals in the Iranian spaghetti samples. However, a significant positive correlation was found between $\mathrm{Al}$ and $\mathrm{Cr}$ concentrations $(\mathrm{r}=0.850)$ and between $\mathrm{Al}$ and $\mathrm{Zn}$ concentrations $(\mathrm{r}=0.597)$, and also between the $\mathrm{Cr}$ and $\mathrm{Zn}$ concentrations $(\mathrm{r}=0.878)$ in the imported spaghetti samples.

The results of the independent t-test and Duncan's multiple range test demonstrated that a significant difference was found between the Iranian and imported spaghetti samples and also between some brands of spaghetti in terms of the contents of $\mathrm{Al}, \mathrm{Cr}, \mathrm{Pb}$, and $\mathrm{Zn}$ $(\mathrm{P}<0.05)$, respectively.

\section{Discussion}

The current study was conducted to analyze the content and also health risk assessment of heavy metals (i.e. $\mathrm{Al}, \mathrm{Cr}, \mathrm{Pb}$, and $\mathrm{Zn}$ ) through the consumption of some Iranian and imported spaghetti marketed in the city of Kermanshah, Iran, in 2015.

Exposure to high amounts of $\mathrm{Al}$ can lead to several serious adverse effects such as osteomalacia, colic, fatigue, 
Table 1. Heavy metal concentrations (Mean \pm SD) of the spaghetti samples $(\mu \mathrm{g} / \mathrm{kg}, \mathrm{DW})$

\begin{tabular}{|c|c|c|c|c|c|}
\hline & \multirow{3}{*}{ Sample } & \multicolumn{4}{|c|}{ Mean \pm SD } \\
\hline & & \multicolumn{4}{|c|}{ Metal Concentration } \\
\hline & & Aluminum & Chromium & Lead & Zinc \\
\hline \multirow{10}{*}{ 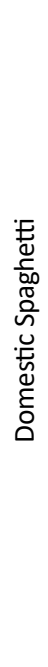 } & 1 & $400.0 \pm 82.0^{\mathrm{ab} *}$ & $200.0 \pm 85.0^{\mathrm{ab}}$ & $2200.0 \pm 1000.0^{\mathrm{ab}}$ & $600.0 \pm 64.0^{\mathrm{abc}}$ \\
\hline & 2 & $600.0 \pm 128.0^{\mathrm{b}}$ & $400.0 \pm 123.0^{c}$ & $2300.0 \pm 970.0^{\mathrm{bc}}$ & $500.0 \pm 44.0^{\mathrm{ab}}$ \\
\hline & 3 & $400.0 \pm 90.0^{\mathrm{ab}}$ & $300.0 \pm 96.0^{b c}$ & $2100.0 \pm 800.0^{\mathrm{ab}}$ & $600.0 \pm 49.0^{\mathrm{abc}}$ \\
\hline & 4 & $1000.0 \pm 289.0^{c}$ & $100.0 \pm 29.0^{\mathrm{a}}$ & $2000.0 \pm 640.0^{\mathrm{a}}$ & $600.0 \pm 55.0^{\mathrm{abc}}$ \\
\hline & 5 & $1500.0 \pm 314.0^{d}$ & $200.0 \pm 81.0^{\mathrm{ab}}$ & $2500.0 \pm 810.0^{c}$ & $600.0 \pm 61.0^{\mathrm{abc}}$ \\
\hline & 6 & $900.0 \pm 270.0^{c}$ & $200.0 \pm 70.0^{\mathrm{ab}}$ & $2000.0 \pm 500.0^{\mathrm{a}}$ & $500.0 \pm 57.0 \mathrm{ab}$ \\
\hline & 7 & $400.0 \pm 70.0^{\mathrm{ab}}$ & $200.0 \pm 62.0^{\mathrm{ab}}$ & $2900.0 \pm 1100.0^{d}$ & $800.0 \pm 245.0^{c}$ \\
\hline & 8 & $300.0 \pm 49.0^{\mathrm{a}}$ & $100.0 \pm 37.0^{\mathrm{a}}$ & $3000.0 \pm 820.0^{d}$ & $400.0 \pm 173.0^{\mathrm{a}}$ \\
\hline & 9 & $400.0 \pm 68.0^{\mathrm{ab}}$ & $200.0 \pm 92.0^{\mathrm{ab}}$ & $5000.0 \pm 1210.0^{\mathrm{e}}$ & $700.0 \pm 112.0^{\text {bc }}$ \\
\hline & Concentration & $655.56 \pm 400.35$ & $211.11 \pm 92.80$ & $2666.67 \pm 948.68$ & $588.89 \pm 116.67$ \\
\hline \multirow{10}{*}{ 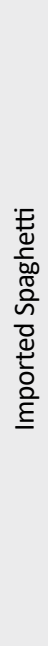 } & 1 & $300.0 \pm 75.0^{\mathrm{a}}$ & $500.0 \pm 105.0^{\mathrm{bc}}$ & $2500.0 \pm 740.0^{b}$ & $600.0 \pm 53.0^{\mathrm{b}}$ \\
\hline & 2 & $500.0 \pm 118.0^{\mathrm{a}}$ & $300.0 \pm 57.0^{\mathrm{a}}$ & $4300.0 \pm 900.0^{f}$ & $700.0 \pm 60.0 \mathrm{~b}$ \\
\hline & 3 & $500.0 \pm 66.0^{\mathrm{a}}$ & $400.0 \pm 92.0^{\mathrm{ab}}$ & $3500.0 \pm 710.0^{d}$ & $600.0 \pm 41.0^{c}$ \\
\hline & 4 & $5000.0 \pm 0.00^{f}$ & $1000.0 \pm 149.0^{d}$ & $2200.0 \pm 620.0^{\mathrm{a}}$ & $1000.20 \pm 615.0^{c}$ \\
\hline & 5 & $3500.0 \pm 0.00^{\mathrm{e}}$ & $1400.0 \pm 111.0^{\mathrm{e}}$ & $4100.0 \pm 664.0^{\text {ef }}$ & $2500.20 \pm 917.0^{d}$ \\
\hline & 6 & $5000.0 \pm 0.10^{g}$ & $1100.0 \pm 101.0^{\mathrm{d}}$ & $3100.0 \pm 542.0^{c}$ & $1200.00 \pm 588.0^{c}$ \\
\hline & 7 & $1500.0 \pm 410.0^{d}$ & $600.0 \pm 160.0^{c}$ & $3000.0 \pm 497.0^{c}$ & $700.00 \pm 302.0^{b}$ \\
\hline & 8 & $800.0 \pm 190.0^{b}$ & $300.0 \pm 98.0^{\mathrm{a}}$ & $4000.0 \pm 491.0^{\mathrm{e}}$ & $200.00 \pm 99.0^{\mathrm{a}}$ \\
\hline & 9 & $1100.0 \pm 270.0^{c}$ & $500.0 \pm 123.0^{b c}$ & $3000.0 \pm 386.0^{c}$ & $300.00 \pm 103.0^{\mathrm{a}}$ \\
\hline & Concentration & $2022.22 \pm 1940.86$ & $677.78 \pm 393.0$ & $3300.0 \pm 728.0$ & $866.67 \pm 685.57$ \\
\hline
\end{tabular}

* The letters $(a, b, c, d, \ldots)$ represent the significant difference between the mean content of elements in spaghetti specimens that computed by 1-way ANOVA and Duncan multiple range test $(\mathrm{P}=0.05)$.

dementia dialectica, anemia, and other blood disorders, neurodegenerative disorders, reduction of renal function, dental caries, and kidney and liver dysfunctions along with Parkinson and Alzheimer diseases [3]. The results showed that the mean concentrations of Al in Iranian and imported spaghetti samples were $655.56 \pm 400.35$ and $2022.22 \pm 1940.86 \mu \mathrm{g} / \mathrm{kg}$, respectively, and those were higher than maximum permissible limits (MPL). It has been proved that the root apex (root cap, meristem, and elongation zone) is highly sensitive to $\mathrm{Al}$ and accumulates $\mathrm{Al}$ very easily [35].
It has been proven that skin irritation, running nose, irritation to the lining of the nose, nose ulcers, liver damage, kidney failure, breathing problems, and circulatory and nerve disorders are the main effects arising from breathing and or long-term exposure to $\mathrm{Cr}$ (VI) [12]. Major sources of Cr-contamination in the soil include the disposal of $\mathrm{Cr}$ containing wastes and electroplating processes [36]. High contents of Cr causes severe chlorosis, necrosis, and a host of other growth abnormalities and anatomical disorders in plants [37]. 
Table 2. Daily Intakes of Metals (DIM) in mg and Health Risk Index (HRI) for individual heavy metal caused by the spaghetti

\begin{tabular}{|c|c|c|c|c|c|}
\hline \multirow{2}{*}{ Target Population } & \multicolumn{5}{|c|}{ Domestic Spaghetti } \\
\hline & & Aluminum & Chromium & Lead & Zinc \\
\hline \multirow{8}{*}{ Adults } & DIM, mg & $1.59 \times 10-5$ & $5.13 \times 10-6$ & $6.48 \times 10-5$ & $1.43 \times 10-5$ \\
\hline & STD & $9.72 \times 10-6$ & $2.25 \times 10-6$ & $2.30 \times 10-5$ & $2.83 \times 10-6$ \\
\hline & Min & $7.29 \times 10-6$ & $2.43 \times 10-6$ & $4.86 \times 10-5$ & $9.71 \times 10-6$ \\
\hline & Max & $3.64 \times 10-5$ & $9.71 \times 10-6$ & $1.21 \times 10-4$ & $1.94 \times 10-5$ \\
\hline & $\mathrm{HRI}$ & $7.96 \times 10-4$ & $1.71 \times 10-3$ & $1.85 \times 10-2$ & $4.77 \times 10-5$ \\
\hline & STD & $4.86 \times 10-4$ & $7.51 \times 10-4$ & $6.58 \times 10-3$ & $9.44 \times 10-6$ \\
\hline & Min & $3.64 \times 10-4$ & $8.10 \times 10-4$ & $1.39 \times 10-2$ & $3.24 \times 10-5$ \\
\hline & Max & $1.82 \times 10-3$ & $3.24 \times 10-3$ & $3.47 \times 10-2$ & $6.48 \times 10-5$ \\
\hline \multirow{8}{*}{ Children } & DIM & $7.43 \times 10-5$ & $2.39 \times 10-5$ & $3.02 \times 10-4$ & $6.67 \times 10-5$ \\
\hline & STD & $4.54 \times 10-5$ & $1.05 \times 10-5$ & $1.08 \times 10-4$ & $1.32 \times 10-5$ \\
\hline & Min & $3.40 \times 10-5$ & $1.13 \times 10-5$ & $2.27 \times 10-4$ & $4.53 \times 10-5$ \\
\hline & Max & $1.70 \times 10-4$ & $4.53 \times 10-5$ & $5.67 \times 10-4$ & $9.07 \times 10-5$ \\
\hline & HRI & $3.71 \times 10-3$ & $7.97 \times 10-3$ & $8.63 \times 10-2$ & $2.22 \times 10-4$ \\
\hline & STD & $2.27 \times 10-3$ & $3.51 \times 10-3$ & $3.07 \times 10-2$ & $4.41 \times 10-5$ \\
\hline & Min & $1.70 \times 10-3$ & $3.78 \times 10-3$ & $6.48 \times 10-2$ & $1.51 \times 10-4$ \\
\hline & Max & $8.50 \times 10-3$ & $1.51 \times 10-2$ & $1.62 \times 10-1$ & $3.02 \times 10-4$ \\
\hline
\end{tabular}

\begin{tabular}{|c|c|c|c|c|c|}
\hline \multirow{2}{*}{ Target Population } & \multicolumn{5}{|c|}{ Imported Spaghetti } \\
\hline & & Aluminum & Chromium & Lead & Zinc \\
\hline \multirow{8}{*}{ Adults } & DIM & $4.91 \times 10-5$ & $1.65 \times 10-5$ & $8.01 \times 10-5$ & $2.10 \times 10-5$ \\
\hline & STD & $4.71 \times 10-5$ & $9.54 \times 10-6$ & $1.77 \times 10-5$ & $1.66 \times 10-5$ \\
\hline & Min & $7.29 \times 10-6$ & $7.29 \times 10-6$ & $5.34 \times 10-5$ & $4.86 \times 10-6$ \\
\hline & Max & $1.21 \times 10-4$ & $3.40 \times 10-5$ & $1.04 \times 10-4$ & $6.07 \times 10-5$ \\
\hline & HRI & $2.46 \times 10-3$ & $5.49 \times 10-3$ & $2.29 \times 10-2$ & $7.02 \times 10-5$ \\
\hline & STD & $2.36 \times 10-3$ & $3.18 \times 10-3$ & $5.05 \times 10-3$ & $5.55 \times 10-5$ \\
\hline & Min & $3.64 \times 10-4$ & $2.43 \times 10-3$ & $1.53 \times 10-2$ & $1.62 \times 10-5$ \\
\hline & Max & $6.07 \times 10-3$ & $1.13 \times 10-2$ & $2.98 \times 10-2$ & $2.02 \times 10-4$ \\
\hline \multirow{8}{*}{ Children } & DIM & $2.29 \times 10-4$ & $7.68 \times 10-5$ & $3.74 \times 10-4$ & $9.82 \times 10-5$ \\
\hline & STD & $2.20 \times 10-4$ & $4.45 \times 10-5$ & $8.25 \times 10-5$ & $7.77 \times 10-5$ \\
\hline & Min & $3.40 \times 10-5$ & $3.40 \times 10-5$ & $2.49 \times 10-4$ & $2.27 \times 10-5$ \\
\hline & Max & $5.67 \times 10-4$ & $1.59 \times 10-4$ & $4.87 \times 10-4$ & $2.83 \times 10-4$ \\
\hline & HRI & $1.14 \times 10-2$ & $2.56 \times 10-2$ & $1.07 \times 10-1$ & $3.27 \times 10-4$ \\
\hline & STD & $1.10 \times 10-2$ & $1.48 \times 10-2$ & $2.36 \times 10-2$ & $2.59 \times 10-4$ \\
\hline & Min & $1.70 \times 10-3$ & $1.13 \times 10-2$ & $7.12 \times 10-2$ & $7.56 \times 10-5$ \\
\hline & Max & $2.83 \times 10-2$ & $5.29 \times 10-2$ & $1.39 \times 10-1$ & $9.44 \times 10-4$ \\
\hline
\end{tabular}

Huang et al. (2008) reported that $\mathrm{Cr}$ is the least mobile element in wheat grains [38]. The results showed that the mean concentrations of $\mathrm{Cr}$ in Iranian and imported spaghetti samples were $211.11 \pm 92.80$ and $677.78 \pm 393.0$ $\mu \mathrm{g} / \mathrm{kg}$, respectively and those were lower than MPL. Chromium contents in the literature have been reported in the mean concentration of $5490 \mu \mathrm{g} / \mathrm{kg}$ in raw spaghetti samples consumed by students in Italy [11].

Lead is well known for its toxic and adverse health effects. In this regard, the absorption of ingested lead may constitute a serious risk to public health. Some chronic effects of $\mathrm{Pb}$ poisoning are anemia, constipation, and colic $[6,39]$. The results showed that the mean concentrations of $\mathrm{Pb}$ in domestic and imported spaghetti samples were $2666.67 \pm 948.68$ and $3300.0 \pm 728.0 \mu \mathrm{g} / \mathrm{kg}$, respectively and those figures were higher than MPL. The literature review mentioned that the plants do not absorb or accumulate $\mathrm{Pb}$. However, in soils contaminated with a high content of $\mathrm{Pb}$, some $\mathrm{Pb}$ can be taken up [36]. 
Lead contents in the literature have been reported in the mean concentration of $89 \pm 46$ and $245 \pm 140 \mu \mathrm{g} / \mathrm{kg}$ in pasta marketed in Poland and Egypt, respectively [2, 23]. Besides, the obtained results are much higher than the findings of Alberti-Fidanza_et al. (2002) who reported that the concentrations of $\mathrm{Pb}$ in raw spaghetti samples consumed by students in Italy were $2120 \mu \mathrm{g} / \mathrm{kg}$ [11] and also Cuadrado et al., who reported that the concentrations of $\mathrm{Pb}$ in pasta samples collected from Spain were $18.70 \mu \mathrm{g} / \mathrm{kg}$ [40].

Zinc is naturally found in soil, but $\mathrm{Zn}$ concentrations are rising unnaturally due to man-made activities, especially mining, coal, and waste combustion, industrial activities, and steel processing. Many foodstuffs contain certain concentrations of $\mathrm{Zn}$. Plants often have a $\mathrm{Zn}$ uptake that their systems cannot handle due to the accumulation of this element in soils [36]. The results showed that the mean concentrations of $\mathrm{Zn}$ in Iranian and imported spaghetti samples were $588.89 \pm 116.67$ and $866.67 \pm 685.57$ $\mu \mathrm{g} / \mathrm{kg}$, respectively and those amounts were lower than MPL. Zinc content in the literature has been reported in the mean concentration of $3395 \pm 640 \mu \mathrm{g} / \mathrm{kg}$ in spaghetti marketed in Egypt [2]. Moreover, the obtained result is much lower than the findings of Cuadrado et al. (2000) who reported that the concentration of $\mathrm{Zn}$ in pasta samples collected from Spain was $14100 \mu \mathrm{g} / \mathrm{kg}$ [40].

Considering the heavy metal concentrations in studied spaghetti samples with the maximum permissible limits (MPL) established by WHO $(200 \mu \mathrm{g} / \mathrm{kg}$ for $\mathrm{Al}$ and $\mathrm{Pb}$, $1300 \mu \mathrm{g} / \mathrm{kg}$ for $\mathrm{Cr}$, and $50000 \mu \mathrm{g} / \mathrm{kg}$ for $\mathrm{Zn}$ ) [2, 22, 33], our findings indicated that the mean concentrations of $\mathrm{Al}$ and $\mathrm{Pb}$ in both Iranian and imported spaghetti samples are higher than MPL.

As shown in Table 2, the average HRI values through the consumption of Iranian spaghetti were $2.11 \times 10$ 2 and $9.82 \times 10-2$ for adults and children, respectively. While, the average HRI values through consumption of imported spaghetti were $3.10 \times 10-2$ and $1.44 \times 10-1$ for adults and children, respectively. Therefore, the results showed that the mean HRI values of analyzed metals for adults and children through the consumption of Iranian and imported spaghetti are lower than 1. In this regard, the HRI of all analyzed metals were minimal.

\section{Conclusion}

According to the results, although HRI values in adults and children via the consumption of Iranian and imported spaghetti were within the safe limits $(\mathrm{HRI}<1)$, the mean concentrations of $\mathrm{Al}$ and $\mathrm{Pb}$ in both Iranian and imported spaghetti samples were higher than MPL. Therefore, the control of heavy metals content during wheat cultivation, harvesting process, transportation and storage, and the production process of spaghetti are recommended.

\section{Ethical Considerations}

\section{Compliance with ethical guidelines}

Ethical approval for this article was registered under license No. 98/154 historian January 14, 2020.

\section{Funding}

The author received financial support for this research (Code: 17150508931009) from Islamic Azad University, Hamedan Branch.

\section{Conflict of interest}

The author declared no conflict of interest.

\section{Acknowledgments}

The author is grateful to Islamic Azad University, Hamedan Branch, for providing facilities to conduct this study.

\section{References}

[1] Jarup L. Hazards of heavy metal contamination. Br Med Bull. 2003; 68(1):167-82. [DOI:10.1093/bmb/ldg032] [PMID]

[2] Salama AK, Radwan MA. Heavy metals $(\mathrm{Cd}, \mathrm{Pb})$ and trace elements $(\mathrm{Cu}, \mathrm{Zn})$ contents in some foodstuffs from the Egyptian market. Emir J Food Agric. 2005; 17(1):34-42. [DOI:10.9755/ejfa.v12i1.5046]

[3] Rezaei Raja O, Sobhanardakani S, Cheraghi M. Heavy metals health risk assessment via consumption of citrus in Hamedan City, potential risk of $\mathrm{Al}$ and $\mathrm{Cu}$. Environ Health Eng Manag J 2016; 3(3):131-5. [DOI:10.15171/EHEM.2016.11]

[4] Sobhanardakani S. Tuna fish and common kilka: Health risk assessment of metal pollution through consumption of canned fish in Iran. J Consum Prot Food Saf. 2017; 12(2):15763. [DOI:10.1007/s00003-017-1107-z]

[5] Tuzen M, Soylak M. Trace heavy metal levels in microwave digested honey samples from middle Anatolia, Turkey. J Food Drug Anal. 2005; 13(4):3437. [DOI:10.38212/2224-6614.2571]

[6] Duran A, Tuzen M, Soylak M. Trace metal contents in chewing gums and candies marketed in Turkey. Environ Monit Assess. 2009; 149(1-4):283-9. [DOI:10.1007/s10661-008-0202-0] [PMID]

[7] Hosseini SM, Sobhanardakani S, Navaei MB, Kariminasab M, Aghilinejad SM, Regenstein JM. Metal content in caviar of wild Persian sturgeon from the southern Caspian Sea. Environ Sci Pollut Res. 2013; 20(8):5839-43. [DOI:10.1007/s11356013-1598-9] [PMID] 
[8] Gopalani M, Shahare M, Ramteke DS, Wate SR. Heavy metal content of potato chips and biscuits from Nagpur City, India. Bull Environ Contam Toxicol. 2007; 79(4):384-7. [DOI:10.1007/s00128-007-9256-x] [PMID]

[9] Stankovska E, Stafilov T, Šajn R. Monitoring of trace elements in honey from the Republic of Macedonia by atomic absorption spectrometry. Environ Monit Assess. 2008; 142(13):117-26. [DOI:10.1007/s10661-007-9913-x] [PMID]

[10] Saracoglu S, Tuzen M, Soylak M. Evaluation of trace element contents of dried apricot samples from Turkey. J Hazard Mater. 2009; 167(1-3):647-52. [DOI:10.1016/j.jhazmat.2009.01.011] [PMID]

[11] Alberti-Fidanza A, Burini G, Perriello G. Trace elements in foods and meals consumed by students attending the faculty cafeteria. Sci Total Environ. 2002; 287(1-2):133-40. [DOI:10.1016/S0048-9697(01)01009-9]

[12] Sobhanardakani S. Potential health risk assessment of $\mathrm{Cr}$ $\mathrm{Cu}, \mathrm{Fe}$ and $\mathrm{Zn}$ for human population via consumption of commercial spices; a case study: Hamedan City, Iran. Int Arch Health Sci. 2016; 3(3):119-24. [DOI:10.18869/IAHS.3.3.119]

[13] Sobhanardakani S, Maanijou M, Asadi H. [Investigation of Pb, $\mathrm{Cd}, \mathrm{Cu}$ and $\mathrm{Mg}$ concentrations in groundwater resources of Razan Plain (Persian)]. Sci J Hamadan Univ Med Sci. 2015; 21(4):319-29.

[14] Needleman H. Lead poisoning. Annu Rev Med. 2004; 55:20922. [DOI:10.1146/annurev.med.55.091902.103653] [PMID]

[15] Finster ME, Gray KA, Binns HJ. Lead levels of edibles grown in contaminated residential soils: a field survey. Sci Total Environ. 2004; 320(2-3):245-57. [DOI:10.1016/j.scitotenv.2003.08.009] [PMID]

[16] Liu W, Zhou Q, Zhang Y, Wei S. Lead accumulation in different Chinese cabbage cultivars and screening for pollution-safe cultivars. J Environ Manag. 2010; 91(3):781-8. [DOI:10.1016/j.jenvman.2009.10.009] [PMID]

[17] Sobhanardakani S, Jamshidi K. Assessment of metals (Co, $\mathrm{Ni}$, and $\mathrm{Zn}$ ) content in the sediments of Mighan Wetland using geo-accumulation index. Iran J Toxicol. 2015; 30:1386-90.

[18] World Health Organization. WHO human health risk assessment toolkit: chemical hazards. international programme on chemical safety; Geneva, Switzerland: World Health Organization; 2010.

[19] Sobhanardakani S. Health risk assessment of As and Zn in canola and soybean oils consumed in Kermanshah City. J Adv Environ Health Res. 2016; 4(2):62-7.

[20] Ru QM, Feng Q, He JZ. Risk assessment of heavy metals in honey consumed in Zhejiang province, southeastern China. Food Chem Toxicol. 2013; 53:256-62. [DOI:10.1016/j. fct.2012.12.015] [PMID]

[21] Liang Q, Xue ZJ, Wang F, Sun ZM, Yang ZX, Liu SQ. Contamination and health risks from heavy metals in cultivated soil in Zhangiiakou City of Hebei Province, China. Environ Monit Assess. 2015; 187(12):754. [DOI:10.1007/s10661-0154955-y] [PMID]

[22] Hariri E, Abboud MI, Demirdjian S, Korfali S, Mroueh M, Taleb RI. Carcinogenic and neurotoxic risks of acrylamide and heavy metals from potato and corn chips consumed by the Lebanese population. J Food Compos Anal. 2015; 42:91-7. [DOI:10.1016/j.jfca.2015.03.009]
[23] Fiłon J, Ustymowicz-Farbiszewska J, Górski J, Karczewski J. Contamination of cereal products with lead and cadmium as a factor of a health risk for people in Podlaskie Voivodship. Vet Med Zoot. 2013; 63(85):29-36.

[24] Iwegbue CM. Metal contents in some brands of biscuits consumed in southern Nigeria. Am J Food Technol. 2012; 7(8):160-7. [DOI:10.3923/ajft.2012.160.167]

[25] Ghasemkhani H, Sobhanardakani S, Cheraghi M. [Health risk assessment of consumption of commercial fruit juices marketed in Hamedan City based on potential risk of $\mathrm{Zn}$ and Cd (Persian)]. J Neyshabur Univ Med Sci. 2016; 4(2):32-40.

[26] Khan S, Cao Q, Zheng YM, Huang YZ, Zhu YG. Health risks of heavy metals in contaminated soils and food crops irrigated with wastewater in Beijing, China. Environ Pollut. 2008; 152(3):686-92. [DOI:10.1016/j.envpol.2007.06.056] [PMID]

[27] Jan FA, Ishaq M, Khan S, Ihsanullah I, Ahmad I, Shakirullah M. A comparative study of human health risks via consumption of food crops grown on wastewater irrigated soil (Peshawar) and relatively clean water irrigated soil (lower Dir). J Hazard Mater. 2010; 179(1-3):612-21. [DOI:10.1016/j. jhazmat.2010.03.047] [PMID]

[28] Guo J, Yue T, Li X, Yuan Y. Heavy metal levels in kiwifruit orchard soils and trees and its potential health risk assessment in Shaanxi, China. Environ Sci Pollut Res. 2016; 23(14):145606. [DOI:10.1007/s11356-016-6620-6] [PMID]

[29] Abdi F, Atarodi Kashani Z, Mirmiran P, Esteki T. [Surveying global and Iranian food consumption patterns: A review of the literature (Persian)]. J Fasa Uni Med Sci. 2015; 5(2):159-67

[30] Falco G, Ilobet JM, Bocio A, Domingo JL. Daily intake of arsenic, cadmium, mercury, and lead by consumption of edible marine species. J Agric Food Chem. 2006; 54(16):6106-12. [DOI:10.1021/jf0610110] [PMID]

[31] Omar WA, Zaghloul KH, Abdel-Khalek AA, Abo-Hegab S. Risk assessment and toxic effects of metal pollution in two cultured and wild fish species from highly degraded aquatic habitats. Arch Environ Contam Toxicol. 2013; 65(4):753-64. [DOI:10.1007/s00244-013-9935-z] [PMID] [PMCID]

[32] Sobhanardakani S. Potential health risk assessment of heavy metals via consumption of caviar of Persian sturgeon. Mar Pollut Bull. 2017; 123(1-2):34-8. [DOI:10.1016/j.marpolbul.2017.09.033] [PMID]

[33] Sato K, Suzuki I, Kubota H, Furusho N, Inoue T, Yasukouchi Y, Akiyama H. Estimation of daily aluminum intake in Japan based on food consumption inspection results: Impact of food additives. Food Sci Nutr. 2014; 2(4):389-97. [DOI:10.1002/fsn3.114] [PMID] [PMCID]

[34] Zeng X, Wang Z, Wang J, Guo J, Chen X, Zhuang J. Health risk assessment of heavy metals via dietary intake of wheat grown in Tianjin sewage irrigation area. Ecotoxicol. 2015; 24(10):2115-24. [DOI:10.1007/s10646-015-1547-0] [PMID]

[35] Panda SK, Baluska F, Matsumoto H. Aluminum stress signaling in plants. Plant Signal Behav. 2009; 4(7):592-7. [DOI:10.4161/psb.4.7.8903] [PMID] [PMCID]

[36] Wuana RA, Okieimen FE. Heavy metals in contaminated soils: A review of sources, chemistry, risks and best available strategies for remediation. ISRN Ecol. 2011; 2011:1-20. [DOI:10.5402/2011/402647] 
[37] Samantaray S, Rout GR, Das P. Role of chromium on plant growth and metabolism. Acta Physiol Plant. 1998; 20(2):20112. [DOI:10.1007/s11738-998-0015-3]

[38] Huang M, Zhou S, Sun B, Zhao Q. Heavy metals in wheat grain: Assessment of potential health risk for inhabitants in Kunshan, China. Sci Total Environ. 2008; 405(1-3):54-61. [DOI:10.1016/j.scitotenv.2008.07.004] [PMID]

[39] Uluozlu OD, Kinalioglu K, Tuzen M, Soylak M. Trace metal levels in lichen samples from roadsides in East Black Sea Region, Turkey. Biomed Environ Sci. 2007; 20(3):203-7.

[40] Cuadrado C, Kumpulainens J, Carbajal A, Moreiras O. Cereals contribution to the total dietary intake of heavy metals in Madrid, Spain. J Food Compost Anal. 2000; 13(4):495-503. [DOI:10.1006/jfca.2000.0937] 